\title{
GOOGLE CLASSROOM SEBAGAI ALTERNATIF DIGITALISASI PEMBELAJARAN MATEMATIKA DI ERA REVOLUSI INDUSTRI 4.0
}

\author{
Ahmad Muslik \\ MA Al-Azhar Asy-Syarif Indonesia, Jakarta \\ Email: muslikakhmad@gmail.com
}

\begin{tabular}{ll}
\hline & doi) https:// 10.36052/andragogi.v7i2.98 \\
Diterima: 10 Oktober 2019 | Disetujui: 19 Desember 2019 | Dipublikasikan: 30 Desember 2019
\end{tabular}

\begin{abstract}
Abstrak
Tujuan penelitian ini adalah untuk membuktikan apakah google classroom mudah digunakan dan sudah sesuai dengan era digital untuk pembelajaran matematika. Menyeimbangi pergerakan revolusi industri 4.0, guru dituntut untuk bisa memanfaatkan teknologi dalam mengelola pembelajaran, baik teknologi yang bersifat online atau offline. Google classroom merupakan serambi pembelajaran online yang dapat membantu guru dalam memberikan materi, tugas, dan ujian, mudah digunakan dan dapat dipantau secara realtime. Survei dilakukan dengan melibatkan sampel 60 siswa yang tersebar secara random menggunakan teknik classified random sampling. Metode penelitian yang digunakan adalah campuran antara kuantitatif dan kualitatif. Kuantitatif untuk menentukan persentase sampel atas variabel penelitian, sedangkan kualitatif menganalisis deskriptif persentase dengan mengkaitkan penelitian lain yang relevan. Teknik pengumpulan data dilakukan dengan teknik wawancara dan penyebaran angket. Hasil penelitian menunjukan bahwa meskipun siswa yang senang pembelajaran matematika dengan google classroom hanya 57\% tetapi peranan google classsroom sebagai model pembelajaran matematika di era digital cukup diapresiasi sebesar 83\%. Kesimpulan dari penelitian ini adalah google classroom dapat dijadikan alternatif pembelajaran matematika di era digital, termasuk juga untuk pelajaran lain.
\end{abstract}

Kata Kunci: matematika, google classroom, pembelajaran, revolusi industri 4.0

\begin{abstract}
The aim of this research is to prove out whether google classroom is easy to use and is in accordance to the mathematics learning in the digital era. In this industrial revolution 4.0, teachers are required to be able to utilize technology, online or offline, to manage the learning process. Google classroom is an online learning platform that can help teachers with materials, assignments and exams. Moreover, it is also easy to use and can be monitored in real time. The survey involves a sample of 60 students who were randomly scattered using the classified method sampling. The method of this research is a mixture of quantitative and qualitative. Quantitative method is used to determine the percentage of the sample of research variables, while qualitative used to analyze percentages descriptively by other relevant research. Techniques of Data collection were carried out by interviewing and distributing questionnaires. The results showed that although only 57\% students like learning mathematics with Google classroom, 83\% of all correspondents appreciate the role of Google classroom as a model of mathematics learning in the digital age. The conclusion of this study is that Google classroom can be used as an alternative to mathematics learning in the digital age; and this may also be applied in other subjects.
\end{abstract}

Keywords: mathematics, google classroom, learning, industrial revolution 4.0 


\section{PENDAHULUAN}

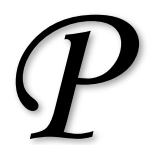

esatnya perkembangan teknologi tidak dapat dipungkiri merambah ke dalam aspek pendidikan. Dunia pendidikan dianggap sebagai salah satu yang memiliki potensi untuk dijadikan bisnis digital dewasa ini. Akibatnya, berbagai upaya developer web baik tingkat lokal maupun internasional mencoba membangun aplikasi dan sarana pendukung untuk meletakan bisnis tersebut dalam lingkaran mereka. Pengusaha web kelas raksasa seperti google dengan google classroom dan microsoft dengan Office365 sudah memfasilitasi dan memberikan ruang khusus dalam webnya untuk pembelajaran digital. Tidak hanya itu, bahkan beberapa perusahaan merk handphone juga melakukan hal sama, sebut saja samsung. Belum lagi untuk perusahaan lain yang memiliki orientasi pendidikan dengan menghasilkan produk web dalam pengembangan pembelajaran digital baik yang gratis maupun berbayar, misalnya moodle, Zenius, Ruangguru, HarukaEdu, Kelase, KelasKita, PesonaEdu, MejaKita, SemuaGuru, Squline, AsDos, 7Pagi, dan sebagainya.

Indonesia sebagai negara dengan jumlah penduduk terbesar ke-4 di dunia memiliki kans yang cukup besar untuk dijadikan objek bisnis, salah satunya melalui pendidikan. Pendidikan merupakan investasi jangka panjang, long term investment, yang produknya berupa kualitas sumber daya manusia. Dengan sumber daya manusia yang unggul, secara langsung akan berdampak pada pembangunan nasional. Oleh karena itu, pemerintah akan menggelontorkan anggaran yang cukup besar untuk pendidikan. Di sisi lain, mencapai tujuan pendidikan yang diterjemahkan menjadi kualitas sumber daya manusia bukan sesuatu yang mudah dilaksanakan. Keterkaitan antara satu unsur dan unsur lain tidak dapat disepelekan. Salah satu unsur yang memiliki peran penting adalah guru atau pendidik. Pendidik tidak akan bisa diganti oleh apapun dan siapapun, karena pendidik tidak hanya memberikan ilmu yang ditekuni melainkan juga nilai yang terkandung dalam kesehariannya.

Dalam konteks pembelajaran di kelas, pendidik pada era digital harus mampu memanfaatkan sarana digital baik online atau offline untuk dijadikan media dalam mengajar. Menjamurnya gawai yang bisa dikatakan hampir semua siswa memiliki, dapat digunakan untuk melakukan proses tranformasi materi dari manual menjadi virtual. Salah satu media yang dapat dijadikan rujukan untuk pembelajaran berbasis online adalah google classroom. Survei yang dilakukan penulis pada 60 responden secara classified random sampling, di Madrasah Aliyah Al-Azhar Asy-Syarif Indonesia Jakarta menjawab beberapa rumusan masalah, misalnya; Apakah siswa yang menggunakan internet lebih dari 90\%? Apakah siswa senang belajar menggunakan google classroom? Apakah google classroom mudah digunakan untuk pembelajaran matematika? Bagaimana penerapan google classroom? 
Sebagai bawaan dari perusahaan raksasa Google, google classroom memiliki akses di lebih dari 45 negara. Google classroom merupakan suatu serambi pembelajaran campuran yang diperuntukkan terhadap setiap ruang lingkup pendidikan yang dimaksudkan untuk menemukan jalan keluar atas kesulitan dalam membuat, membagikan dan menggolonggolongkan setiap penugasan tanpa kertas. Dari definisi, tersurat jelas tujuannya, yaitu memudahkan pendidik dalam pembelajaran dan memberikan tugas-tugas tanpa kertas. Tujuan ini seirama dengan pembejaran digital yang meminimalisisir penggunaan kertas dan pemanfaatan teknologi. Prinsipnya, google classroom hanya sebuah media atau alat yang dapat digunakan oleh pendidik dan siswa untuk menciptakan kelas online atau kelas virtual, di mana pendidik dan siswa dapat melakukan pembelajaran secara langsung. Desain google classroom diperuntukan bagi pengajar, siswa, wali dan administrator. Pengajar dapat menggunakan fasilitas membuat dan mengelola kelas, tugas, nilai serta memberikan masukan secara langsung (real-time). Siswa sendiri dapat memantau materi dan tugas kelas, berbagi materi dan berinteraksi dalam aliran kelas atau melalui email, mengirim tugas dan mendapat masukan dan nilai secara langsung. Adapun wali dapat memanfaatkan ringkasan email yang memuat tugas siswa. Ringkasan ini meliputi informasi tentang tugas yang tidak dikerjakan, tugas selanjutnya dan aktivitas kelas. Namun wali tidak bisa login ke kelas secara langsung. Wali hanya menerima ringkasan email melalui akun lain. Untuk administrator dapat membuat, melihat atau menghapus kelas di domainnya, menambahkan atau menghapus siswa dan pengajar dari kelas serta melihat tugas di semua kelas di domainnya.

Teknologi dapat menjadi ancaman bagi kalangan tertentu, tetapi teknologi juga dapat menjadi tantangan sekaligus harapan bagi yang lain. Salah satu tantangan teknologi dalam masyarakat adalah masuknya teknologi dalam dunia pendidikan. Pendidikan harus menerima dan beradaptasi dengan teknologi untuk bisa memfasilitasi siswa. Penerimaan teknologi dalam pendidikan paling tidak sesuai dengan beberapa model;

a. Theory Reasoned Action

Menurut Theory Reasoned Action (TRA), perilaku seseorang berdasar pada keyakinan, niat, norma, dan sikap yang diperolehnya terhadap sesuatu. Secara sederhana teori ini digambarkan sebagai berikut.

Behavioral Intention = Attitude + Subjective norms

Ketika seseorang berkehendak, maka keyakinan yang muncul dalam diri seseorang adalah mampu menggagalkan atau mensukseskan subjeknya.

b. Technology Acceptance Model (TAM)

Pada tahun 1986, Davis memperkenalkan model ini dengan tujuan ingin memprediksi penerimaan terhadap teknologi. Menurutnya, ada 
dua faktor penerimaan terhadap teknologi, yaitu penerimaan kegunaannya (perceived usefulness) dan penerimaan kemudahan dalam menggunakan (perceived ease of use). Artinya, sebuah teknologi akan diterima dengan baik oleh masyarakat jika memenuhi unsur manfaat dan kemudahan (Davis \& Bagozzi, 1989).

Perceived usefulness diartikan sebagai derajat di mana seseorang percaya bahwa dengan menggunakan sistem dapat meningkatkan kinerjanya sedangkan untuk perceived ease of use berkaitan dengan keyakian seseorang bahwa menggunakan sistem akan menjadi effortless. Lebih lanjut Davis mengatakan sikap dari individu bukan faktor utama yang menentukan kegunaannya terhadap suatu sistem, tetapi juga berdasarkan dampak yang mempengaruhi kinerjanya.

c. Unified Theory of Acceptance and Use of Technology (UTAUT)

Menurut Venkatesh, teori ini berkaitan dengan beberapa faktor yang mempengaruhi niat berperilaku (behavioural intentions) untuk menggunakan teknologi tertentu. Harapan kinerja (performance expectancy), harapan usaha (effort expectancy) dan pengaruh sosial (social influence) merupakan tiga kompenen utama yang mempengaruhi niat dalam berperilaku terhadap penggunaan teknologi.

Harapan kinerja (performance expectancy) merupakan derajat di mana individu (pengguna) mengharapkan bahwa dengan menggunakan sistem dapat membantu memperoleh keuntungan atau kemudahan dalam kinerjanya. Kemudian harapan usaha (effort expectancy) merupakan derajat kemudahan yang berhubungan dengan penggunaan sistem. Pengaruh sosial (social influence) merupakan derajat di mana individu menganggap penting bagi orang lain untuk menerima bahwa ia harus menggunakan sistem yang baru.

\section{METODE PENELITIAN}

Pada penelitian ini, penulis menggunakan metode analisis deskriptif, yaitu menganalisis data yang ada dan menggambarkan kondisi yang sebenarnya dari sampel.

Populasi dalam penelitian ini adalah semua siswa yang berada di MA Al-Azhar Asy-Syarif Indonesia Jakarta Selatan yang berjumlah 157 siswa yang tersebar dalam 9 kelas, yaitu X IPA, X IPS, X AGAMA, XI IPA, XI IPS, XI AGAMA, XII IPA, XII IPS, dan XII AGAMA.

Teknik pengambilan sampel menggunakan classified random sampling, yaitu mengacak kelas untuk dipilih dan dijadikan sampel. Dari sembilan kelas, terpilih tiga kelas yaitu XII IPS, XII IPA, dan XI IPS dengan jumlah sampel 58 siswa.

Teknik pengumpulan data yang penulis gunakan adalah wawancara dan angket. Wawancara dalam hal ini adalah semi terstruktur dengan tujuan peneliti dapat mengembangkan pertanyaanpertanyaan lain sehingga tujuan penelitian tentang google class room dapat terpenuhi. 
Pengembangan instrumen yang penulis lakukan melalui uji validitas butir atau indeks konsistensi internal, yaitu korelasi rxy antara skor butir angket dan skor total dan reliabilitas angket instrumen menggunakan alpha cronbach dengan melakukan uji coba instrumen di kelas yang bukan menjadi sampel penelitian sebanyak satu kelas. Dari 10 pernyataan, penulis hanya menggunakan 5 pernyataan yang memiliki indeks konsistensi internal lebih dari 0,3.

Data angket yang diperoleh dihitung menggunakan rumus persentase per item pernyataan dengan rumus $P=$ (skor item/skor maksimal) x 100\%.

\section{HASIL DAN PEMBAHASAN}

\section{Temuan}

\section{a. Gambaran Objek Penelitian}

MA Al-Azhar Asy-Syarif Indonesia merupakan satu-satunya madrasah aliyah yang memiliki keunikan dari madrasah aliyah lain. Satu hal yang membuat unik adalah pelajaran yang diberikan kepada siswa, yaitu pelajaran serupa dengan pelajaran tingkat menengah di Mesir. Pelajaran yang dimaksud bukan seperti fikih, quran hadits, SKI, dan akidah akhlak tetapi ada penambahan ushul fikih, nahwu-shorof, tarikh, tauhid, ilmu kalam, mutholaah, tafsir, hadits, insya, dan tahfizul quran.

Selain penambahan pelajaran itu, madrasah yang bekerjasama dengan alazhar Mesir, juga memakai kurikulum nasional sebagai kurikulum utama tingkat menengah. Oleh karena itu, siswa yang belajar di MA Al-Azhar Asy-Syarif harus siap dengan segudang pelajaran dan tentu saja juga tugas yang akan diembannya.

MA AL-Azhar Asy-Syarif mulai tahun 2016 membuka tiga peminatan di tiap level, yaitu IPA, IPS, dan Agama sehingga sampai tahun ini menampung sembilan rombongan belajar. Untuk materi-materi agama atau biasa disebut materi alazhar, tenaga pengajar diambil dari lulusan Al-Azhar Mesir dan Timur Tengah (90\%), sisanya (10\%) dari UIN Jakarta dan PTIQ Jakarta. Adapun mata pelajaran umum sebagian besar diampu oleh pengajar dari MAN 4 Jakarta sebagai kelas filialnya dengan latar belakang yang linier dan pengalaman bertahun-tahun dalam mengajar.

Terkait dengan pembelajaran matematika, MA Al-Azhar Asy-Syarif memiliki dua guru bersertifikat matematika yang bertanggungjawab pada mutu matematika siswa. Salah satu pengajar matematika sering memanfaatkan teknologi sebagai media dalam pembelajarannya, misalkan saja google class room. Bagi pengajar matematika, google class room sangat cocok diterapkan untuk pembelajaran karena selain mudah, konten dan menu yang disajikan juga sudah familier.Temuan berupa kenyataan di lapangan diintegrasikan/ dikaitkan dengan hasil-hasil penelitian sebelumnya atau dengan teori yang sudah ada. Untuk keperluan ini harus ada rujukan. Dalam memunculkan teoriteori baru, teori-teori lama bisa dikonfirmasi atau ditolak, sebagian mungkin perlu memodifikasi teori dari teori lama. 


\section{b. Profil Google Classoom}

Google classroom merupakan sistem pembelajaran yang bertujuan untuk kemudahan dalam membuat dan memberikan tugas kepada siswa dengan sifat tugas yang paperless. Untuk login ke google classroom, pengguna akun gmail hanya mencari dan klik menu google classroom yang sudah tersedia di akun gmail yang bersangkutan. Beberapa tampilan google classroom penulis sajikan sebagai berikut.

\section{1) Kelas}

Administrator atau bisa juga guru dapat membuat kelas melalui menu kelas. Siswa dapat bergabung dengan kelas dapat melalui dua cara, yaitu diundang via email atau login dengan kode kelas yang tersedia dalam masing-masing kelas yang telah dibuat.

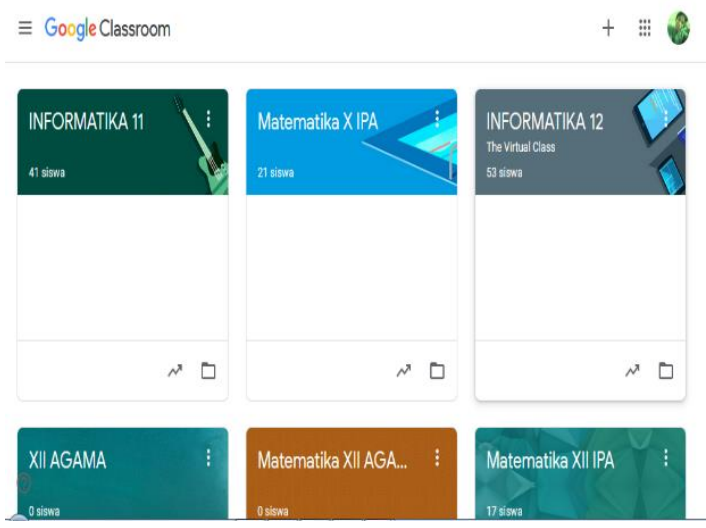

Gambar 1. Kelas dalam google classroom

Gambar 1 merupakan kelas yang penulis ampu. Dalam gambar 1 penulis mengelola 6 kelas, yaitu informatika 11, matematika $x$, informatika 12, matematika 12 agama dan matematika 12 IPA. Screenshoot hanya menampilkan 6 kelas, yang sebenarnya penulis mengelola 10 kelas.

2) Forum
Menu forum bertujuan untuk memberikan kesempatan diskusi antara siswa dan guru. Menu forum berada pada masing-masing kelas.

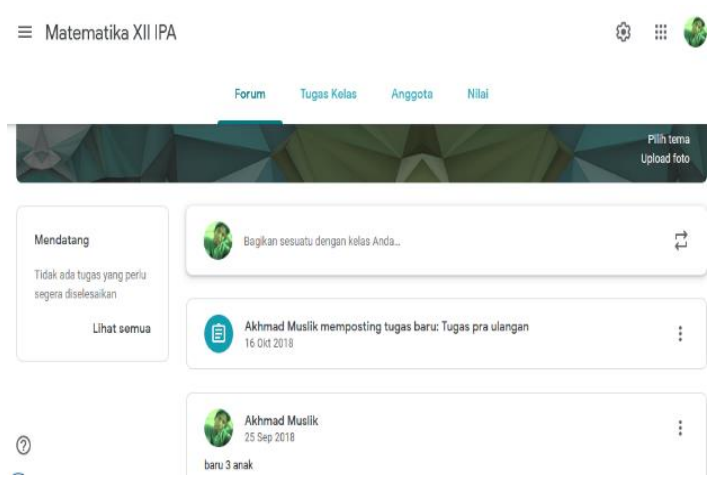

Gambar 2. Tampilan menu forum

Pada menu forum, siswa dapat melihat aktivitas pembelajaran, baik itu tugas, materi, topik dan sebagainya.

3) Tugas Kelas

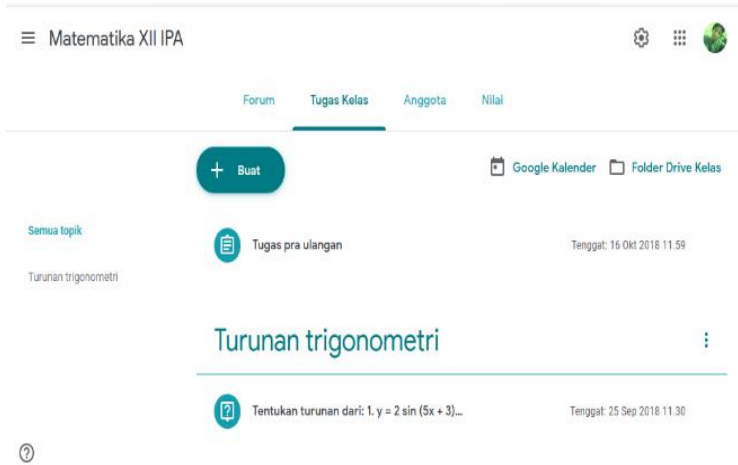

Gambar 3. Tampilan menu tugas kelas

Gambar 3 adalah menu tugas kelas sebagai tempat pembuatan tugas, kuis, bahan ajar, topik, pertanyaan, dan postingan.

4) Anggota

Jumlah dan nama anggota atau peserta akan tampil dalam menu ini. 


\section{Akhmad Musilk}

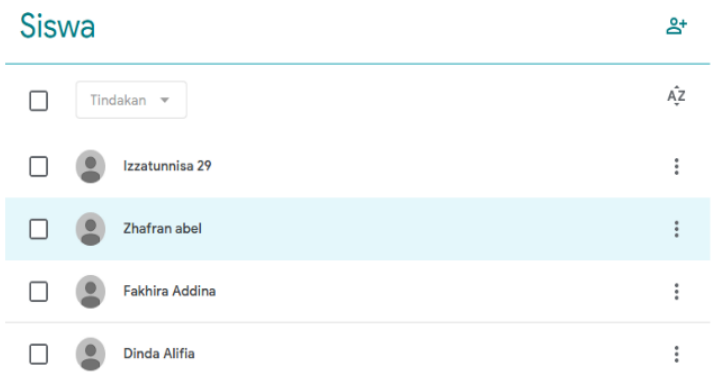

Gambar 4. Tampilan menu anggota

5) Nilai

$\equiv$ Matematika XII IPA

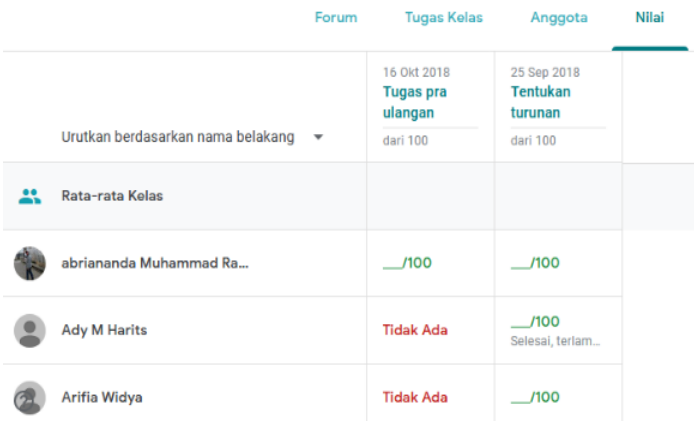

Gambar 5. Tampilan menu penilian

Gambar 5 menampilkan tabel penilaian yang dapat dilakukan guru. Siswa yang tidak mengerjakan tugas atau ujian ditampilkan pada menu ini. Siswa hanya dapat melihat nilai masing-masing dalam akunnya. Untuk soal uraian yang berbeda bobot penilaiannya, google classroom memberikan alternatif pilihan dengan masuk pada menu setting kelas.

\section{Pembahasan}

Pembahasan penelitian dianalisis dari data yang diambil dari sampel dengan mengaitkan teori, penelitian, atau sumber lain.

\section{Penggunaan Internet}

Tabel 1. Penghitungan variabel penggunaan internet

\begin{tabular}{lcccc}
\hline Penggunaan & \multicolumn{4}{c}{ Jawaban } \\
\cline { 2 - 5 } Internet & SS & S & TS & STS \\
\hline Pilihan & 176 & 45 & 2 & 0 \\
Persentase & 73 & 19 & & \\
& $\%$ & $\%$ & $1 \%$ & $0 \%$ \\
Total & \multicolumn{5}{c}{$93 \%$} \\
Skor maksimal & \multicolumn{5}{c}{$4 \times 60=240$} \\
\hline
\end{tabular}

Tabel 1. memberi penjelasan bahwa 93\% siswa di MA Al-Azhar Asy-Syarif Indonesia menggunakan internet setiap hari, sisanya $7 \%$ hanya menggunakan internet sesuai kebutuhan. Dari data tersebut juga tergambar $73 \%$ siswa sangat setuju dengan penggunaan internet setiap hari, $19 \%$ setuju, dan $1 \%$ tidak setuju.

Hasil tersebut seirama dengan polling yang telah dilakukan Asosiasi Pengguna Jasa Internet Indonesia (APJII) yang melibatkan 5.900 sampel dengan margin of error 1,28 persen. Selama periode Maret hingga 14 April 2019, dari total populasi sebanyak 264 juta jiwa penduduk Indonesia, ada sebanyak 171,17 juta jiwa atau sekitar 64,8 persen yang sudah terhubung ke internet. Hasil ini mengalami peningkatan yang signifikan dari dua tahun sebelumnya sebanyak 54,86 persen. Dari peningkatan pengguna internet, penetrasi terbanyak berada di pulau jawa, disusul Sumatera. (Kompas, 16 Mei 2019, online). 


\section{Ketertarikan dengan Matematika}

Tabel 2. Penghitungan variabel ketertarikan dengan matematika

\begin{tabular}{lcccc}
\hline $\begin{array}{l}\text { Ketertarikan } \\
\text { dengan }\end{array}$ & \multicolumn{4}{c}{ Jawaban } \\
Matematika & S & TS & STS \\
\hline $\begin{array}{l}\text { Pilihan } \\
\text { Persantase }\end{array}$ & 32 & 99 & 30 & 4 \\
jawaban & $13 \%$ & $41 \%$ & $13 \%$ & $2 \%$ \\
$\begin{array}{l}\text { Persentase total } \\
\text { Skor maksimal }\end{array}$ & \multicolumn{4}{c}{$69 \%$} \\
\hline
\end{tabular}

Dari tabulasi dan penghitungan data responden pada tabel 2, 69\% siswa di MA Al-Azhar Asy-Syarif Indonesia tertarik dengan pelajaran matematika, sisanya $31 \%$ menganggapnya tidak tertarik. Dari data tersebut juga tergambar 13\% siswa sangat setuju dengan ketertarikan matematika, $41 \%$ setuju, $13 \%$ tidak setuju, dan $2 \%$ sangat tidak setuju.

Beragam metode mengajar berakibat pada meningkatnya minat siswa terhadap pelajaran matematika. $\mathrm{Hal}$ ini sesuai juga dengan hasil penelitian Widiastuti dkk, yang menghasilkan lebih dari 90\% siswa minat terhadap pelajaran matematika jika metode yang digunakan bervariasi.

\section{Pembelajaran Matematika dengan Google Classroom}

Tabel 3. Penghitungan variabel pembelajaran matematika dengan google

\begin{tabular}{lcccc}
\multicolumn{4}{c}{ classroom } \\
\hline Pembelajaran & \multicolumn{4}{c}{ Jawaban } \\
Matematika dengan & SS & S & TS & STS \\
Google classroom & 8 & 60 & 62 & 7 \\
\hline Pilihan & 8 & & 26 & $3 \%$ \\
Persantase jawaban & $3 \%$ & $25 \%$ & $\%$ & $3 \%$ \\
& \multicolumn{4}{c}{$57 \%$} \\
Persentase total & $4 \times 60=240$ \\
Skor maksimal &
\end{tabular}

Dari tabulasi dan penghitungan data responden pada tabel 3, 57\% siswa di MA Al-Azhar Asy-Syarif Indonesia senang pembelajaran matematika dengan google classroom, sisanya $\quad 43 \%$ menganggapnya tidak senang. Dari data tersebut juga tergambar $8 \%$ siswa sangat setuju senang pembelajaran matematika dengan google classroom, $60 \%$ setuju, $62 \%$ tidak setuju, dan $7 \%$ sangat tidak setuju.

Sebagai pembanding, hasil pengujian statistik deskriptif untuk variabel pembelajaran akuntansi dari penelitian Wahyuni (2018:61) menghasilkan rata-rata 27,31 dan standar deviasi 4,558 dengan nilai minimum 12 dan nilai maximum 36 . Artinya adalah dari 6 pertanyaan tentang pembelajaran akuntansi, rata-rata responden menjawab dengan poin 4 yaitu Agak Setuju. Oleh karena itu, dapat dikatakan bahwa kecenderungan jawaban yang diberikan oleh responden adalah setuju dengan pernyataanpernyataan yang berkaitan dengan pembelajaran akuntansi. Hasil penelitian ini mengkonfirmasi hasil penelitian penulis.

\section{Kemudahan Google Classroom}

Tabel 4. Kemudahan google classroom

\begin{tabular}{lrccc}
\hline Kemudahan & \multicolumn{4}{c}{ Jawaban } \\
\cline { 2 - 5 } $\begin{array}{l}\text { menggunakan } \\
\text { google class } \\
\text { room }\end{array}$ & SS & S & TS & STS \\
\hline $\begin{array}{l}\text { Pilihan } \\
\text { Persantase }\end{array}$ & 44 & 99 & 30 & 1 \\
jawaban & $18 \%$ & $41 \%$ & $13 \%$ & $0 \%$ \\
$\begin{array}{l}\text { Persentase total } \\
\text { Skor maksimal }\end{array}$ & \multicolumn{4}{c}{$73 \%$} \\
\hline
\end{tabular}


Dari tabel 4. menggambarkan 73\% siswa di MA Al-Azhar Asy-Syarif Indonesia menganggap bahwa google classroom mudah digunakan, sisanya 27\% menganggapnya tidak mudah. Dari data tersebut juga tergambar $18 \%$ siswa sangat setuju senang pembelajaran matematika dengan google classroom, $41 \%$ setuju, 13\% tidak setuju, dan $0 \%$ sangat tidak setuju.

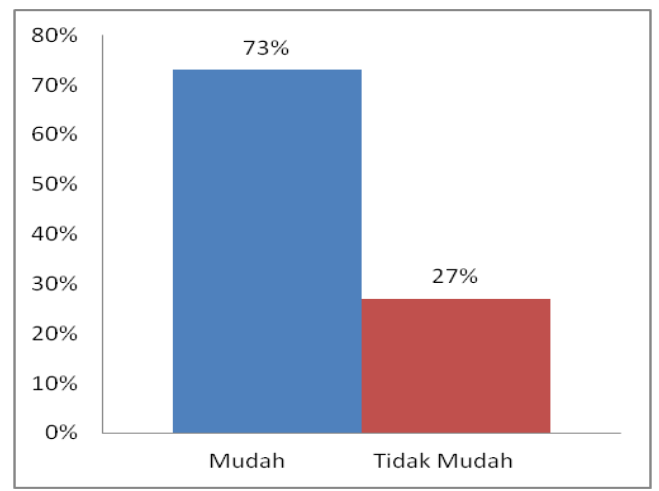

Grafik 1. Persentase Kemudahan penggunaan google classroom

Hasil penelitian ini serasi dengan penelitian yang dilakukan oleh Wahyuni $(2018 ; 29)$ yang menunjukan bahwa rata-rata sampel penelitian sebanyak 314 responden setuju dengan pernyataan bahwa google classroom mudah digunakan. Dari enam pernyataan yang diberikan rata-rata menjawab poin 5 dari rentang 1 - 6 dengan standar deviasi 3,467 dan rata-rata 30,91 .

Kemudahan google classroom bagi siswa menunjukan bahwa siswa merespon teknologi sebagai sesuatu yang memiliki manfaat dan percaya bahwa sistem mampu meningkatkan kinerjanya. Hal tersebut sesuai dengan teori Technology Acceptance Model (TAM) yang dikembangkan oleh Davis pada tahun 1986.

\section{Kesesuaian Google Classroom dengan Era Digital}

Tabel 5. Kesesuaian google classroom dengan era digital

\begin{tabular}{lcccc}
\hline $\begin{array}{l}\text { Kesesuaian google } \\
\text { classroom dengan } \\
\text { era digital }\end{array}$ & \multicolumn{4}{c}{ Jawaban } \\
\hline Pilihan & 92 & 99 & 8 & 0 \\
$\begin{array}{l}\text { Persantase } \\
\text { jawaban }\end{array}$ & $38 \%$ & $41 \%$ & $3 \%$ & $0 \%$ \\
$\begin{array}{l}\text { Persentase total } \\
\text { Skor maksimal }\end{array}$ & \multicolumn{4}{c}{$83 \%$} \\
\hline
\end{tabular}

Tabel 5 memberi penjelasan bahwa 83\% siswa di MA Al-Azhar Asy-Syarif Indonesia menganggap bahwa google classroom sudah sesuai dengan era digital, sisanya $17 \%$ menganggapnya tidak sesuai. Dari data tersebut juga tergambar 38\% siswa sangat setuju google classroom sesuai dengan pembelajaran era digital, $41 \%$ setuju, 3\% tidak setuju, dan $0 \%$ sangat tidak setuju.

Hasil sebesar 83\% menujukan bahwa sasaran google education suite untuk mengembangkan aplikasi pembelajaran dalam pendidikan sudah tercapai. Adapun wawancara penulis dengan beberapa siswa yang menjadi sampel penelitian ada sebagian siswa yang belum sepenuhnya terampil menggunakan google classroom.

\section{PENUTUP}

\section{Simpulan}

Hasil penelitian menunjukan bahwa meskipun siswa yang senang pembelajaran matematika dengan google classroom hanya $57 \%$ tetapi peranan google classsroom sebagai model pembelajaran matematika di era digital cukup diapresiasi sebesar 
83\%. Hal ini berarti, google classroom dapat dijadikan alternatif pembelajaran matematika di era digital termasuk pelajaran-pelajaran lain.

Sebelumnya, hasil penelitian dari Wahyuni, mahasiswa fakultas ekonomi Universitas Islam Indonesia menyimpulkan bahwa performa google classroom berpengaruh positif dalam menunjang pembelajaran akuntansi.

\section{Rekomendasi}

Beberapa saran yang dapat dilakukan untuk pemangku kepentingan:

a. Perlu diadakan pelatihan yang menyeluruh untuk semua guru di Madrasah tentang google classroom.

b. Perlu inovasi pembelajaran yang beragam, manual atau digital, agar warna pembelajaran lebih menarik.

\section{DAFTAR PUSTAKA}

Aparicio, M., Bacao, F., \& Oliveira, T. (2017). Grit in the Path to E-Learning Success. Computers in Human Beaviour, 66, 388-399. doi:https://doi.org/10.1016/j.chb.2016.10.009

Davis, F., \& Bagozzi, R. (1989). User Acceptance of Computer Technology: A Comparison of Two Theoretical Models. Management Science, 35(8), 982-1003. Diambil kembali dari http://www.jstor.org/stable/10.2307/2632151

Eka, W. (2018). Penerapan Google Classroom dalam Pembelajaran Akuntansi. Skripsi, UII.

Google Classroom. (2017). Dipetik Agustus 13, 2019, dari Wikipedia: https://id.wikipedia.org/wiki/Google_Classroom

Izenstark, A., \& Leahy, K. (2015). Google Classroom for Librarians: Features and Opportunities. Library Hi Tech News, 32(9), 1-9. doi:https://doi.org/10.1108/LHTN-05-2015-0039

Murtadho, Sutrisman, \& Tambunan. (1987). Pembelajaran Matematika. Jakarta: UT.

Russefendi, E. (1980). Pengajaran Matematika Modern untuk Orang Tua, Murid, Guru, dan SPG. Bandung: Tarsito.

Sadiman, A. (1984). Media Pendidikan. Jakarta: Raja Grafindo Persada.

Sudjana, N. (1987). Cara Belajar Siswa Aktif. Bandung: PN Sinar Baru. 